\title{
Reflections on Using Journals in Higher Education: A Focus Group Discussion with Faculty
}

\section{Author Biographies:}

Tim O'Connell, Ph.D. is an Associate Professor in the School of Outdoor Recreation, Parks \& Tourism at Lakehead University, Thunder Bay, Ontario, Canada. Tim's research interests include psychosocial dimensions of outdoor recreation, motivations to sea kayak, psychological sense of community, and journal writing.

Janet Dyment, Ph.D. is a Senior Lecturer in Outdoor Education in the Centre for Human Movement in the Faculty of Education at the University of Tasmania, Australia. Her research interests include critical environmental education, urban restoration, and school ground greening.

\section{Acknowledgements:}

We gratefully acknowledge the financial support from Lakehead University's Regional Research Fund, the Outdoor Recreation Student Society Development Fund, as well as the Senate Research Committee. We would also like to thank the faculty who were involved in this research study.

\section{Contact Address:}

Dr. Timothy O’Connell

School of Outdoor Recreation, Parks and Tourism

Lakehead University

955 Oliver Road

Thunder Bay, ON

P7B 5E1

Canada

Telephone: (807) 343-8876

Email: tim.oconnell@lakeheadu.ca 


\begin{abstract}
Reflective journals have become an increasingly popular tool used by numerous faculty across many disciplines in higher education. Previous research and narrative reports of journal writing have explored student perceptions of journal writing, but very little is understood about faculty perceptions. In this paper, we report on a study involving eight university faculty who teach courses with outdoor field components in the areas of outdoor recreation, experiential education, or outdoor education. We present the faculty member's 1) current practices of journal writing (types of journals, types of entries, process of journal writing), 2) perceptions of journal writing (rationale, quality, evaluation), and 3) recommendations to maximize the potential of journal writing. A mixed methods approach was used that included a 32-item quantitative questionnaire and a focus group discussion. By and large, the faculty who participated in this study appreciated the pedagogical potential of journal writing. They were, however, cautious about certain aspects of the journaling process and offered numerous suggestions for improving the "journaling experience.” This paper concludes with several recommendations for consideration by higher education faculty who use journal writing as an instructional technique.
\end{abstract}




\section{Introduction}

A modest body of research has examined the use of journals as a pedagogical tool in higher education. This research suggests that many university and college faculty require students to keep journals in a wide range of courses including, but not limited to, management (King Jr., 1998), psychology (Hettich, 1990), second language instruction (Kerka, 1996), business (Johnson \& Barker, 1995), therapeutic recreation (Murray, 1997), outdoor recreation and leisure studies (Bocarro, 2003; Dyment \& O'Connell, 2003b) research methods (Janesick, 1998), teacher education (Arredondo \& Rucinski, 1994; Wallace \& Oliver, 2003), literature (Cole, 1994), and engineering (Gardner \& Fulwiler, 1999). These researchers describe how journals can be a useful instructional/learning strategy that allows students to reflect critically on material, to ground their learning in their lived experience, to develop their writing skills, and to demonstrate their knowledge/understanding in a non-traditional manner. The research also points to some disadvantages and concerns about journaling, such as the challenges of evaluation and student burnout.

In exploring the use of journals in higher education, many researchers have explored student perceptions and experiences. For example, Arredondo and Rucinski (1994) investigated 69 education students' perceptions of journaling in education courses over a two-year period. In another study in a literature class, Cole (1994) examined 14 students' experiences of journal writing. More recently, Bocarro (2003) explored the experiences of 20 students who kept journals in a service learning course. Earlier phases of our research also explored student perceptions of journal writing in outdoor recreation courses (Dyment \& O'Connell, 2003b; in press).

While this research allows for a rich understanding of how students perceive and experience journal writing in higher education, surprisingly little research has been conducted that explores the perceptions of the faculty who require journals in their classes. Most resources available to faculty are limited to "how-to" books describing the method and activities related to journal writing. Important questions about faculty experiences with, perceptions of, and recommendations for journal writing in higher education remain unanswered. In regards to journal use: How are journals being used? What kinds of journals are being used? What kinds of entries are being written? In regards to faculty perceptions of journals: Why do faculty choose to use journals as a pedagogical tool? How do faculty evaluate journals? Are faculty satisfied with the overall quality of the journals? In regards to recommendations: What recommendations would faculty have to enhance the potential of journal writing? This study explores these questions.

More specifically, this paper describes the fifth phase of a study that examines the use of journals in higher education. Earlier phases explored aspects of journal writing ranging from student perceptions of journaling to a content analysis of 880 student journal entries. A brief summary of the findings and recommendations from these studies follows.

Sixty two students from two universities in North America participated in the first phase of this study. These students responded to a 38 question survey designed to elicit feelings regarding previous, present, and future attitudes and behaviours about journal writing. Students generally agreed that journal writing was a helpful method of encouraging reflection. They also indicated a neutral position towards keeping journals in general. These students were also very interested in learning more about journal writing. Findings revealed that men and women differed significantly in their perception of journaling in many areas (i.e., women were more proud of their journals, and had better attitudes towards journal writing). Students from the two universities had significantly different perceptions of journaling. We postulated these differences were the result of varying levels of experience with journaling as well as differing approaches towards how these journals were evaluated (Dyment \& O'Connell, in press).

Phase 2 of this study examined the impact of a journaling workshop on students' attitudes and behaviours related to journaling. We developed a 45 minute workshop intended to introduce 
students to: Bloom's Taxonomy of Cognitive Thinking (Bloom, 1956), creative writing techniques, and various types of entries that could be written. Participants completed a survey before and after the workshop and subsequent wilderness trip. This study included a control group who did not participate in the workshop. Key findings from this study include differences between men and women in attitudes and behaviours towards journal writing (much the same as those reported in the first phase) and differences between experienced writers and less experienced writers. The workshop had the greatest effect on women who were the least experienced with journal writing (Dyment \& O'Connell, 2003a; O'Connell \& Dyment, 2003).

For the third phase of this project, we conducted a focus group with students who were "practised" journal writers. Key findings from this phase include: student recognition of the freedom journal writing provides as a means of reflection; student concern over the mechanics and intent of grading journal writing assignments; deep-rooted socializations and stereotypes (e.g., it is more acceptable for women to keep "diaries" than men) regarding journal writing may affect attitudes and behaviours related to journal writing; and, perhaps the most interesting finding, that these students perceived themselves to be much more advanced journal writers than they actually were. In essence, they thought they were writing at a much "higher" academic level than what they indicated they were writing in their journals (Dyment \& O'Connell, 2003b).

The fourth phase of this study used a content analysis of over 880 distinct journal entries that were generated from Phase 2 to explore the impact of the journal writing workshop on student writing. The results related to the effects of participation in the workshop presented conflicting findings, and offered no conclusive evidence as to the effectiveness of the workshop. However, we did discover that the majority of students were writing at very basic levels (i.e., reporting facts, making general observations, etc.) (O'Connell \& Dyment, 2004).

Informed by findings from earlier phases of our research, in Phase 5 we were interested in understanding how faculty and instructors ${ }^{1}$ in higher education use and perceive journal writing. We were also interesting in learning about their recommendations to improve the journaling experience in higher education. We begin, however, by presenting a brief review of the literature related to journal writing.

\section{Literature Review}

Keeping a written record of daily events and life experiences has been evident throughout human history, and may be traced back to Greek and Roman times. In the $10^{\text {th }}$ century, Japanese women of the royal courts kept journals on their impressions of daily life. During the Renaissance, enlightened individuals felt obliged to record their experiences. In the Victorian era, people kept track of their religious and political experiences in journals. Perhaps one of the greatest influences on modern journal keeping is westward expansion in North America. Lewis and Clark kept detailed accounts of their personal reactions to their experiences, as well as comprehensive field logs of flora, fauna and other natural history items. Other notable individuals who kept journals include Henry David Thoreau, John Muir, Virginia Wolf, and Anne Frank (Janesick, 1998; Raffan \& Barrett, 1989).

In recent times, journals have been used for a variety of purposes, in a range of learning environments, and with a number of populations. Stemming from past uses in recording experiences for use in developing new knowledge, journal writing is commonly used in the academic world as a method of encouraging students to learn, and as a means of evaluation. Literature, psychology, teacher education, and sociology are academic fields that have traditionally used journals in these ways (Anderson, 1992; Cole, 1994). Students of all ages, demographic groups (e.g., women, non-traditional students, minorities), and education levels are

\footnotetext{
${ }^{1}$ Given that study participants included both faculty (e.g., professors) and instructors (e.g., teaching assistants), for the purposes of this paper, we have used the term 'faculty' to include both.
} 
asked to keep journals (King Jr., 1998; Steiner \& Phillips, 1991; Walden, 1995). Faculty in academic subject areas such as therapeutic recreation, nursing, and psychology ask students to write journals as a way of reflecting on learning, personal development, and positive change (Burt, 1994; Hettich, 1990; Kerka, 1996; Murray, 1997). Journals have also been used in autobiographical accounts, in qualitative research, and in experiential education (Grumet, 1990; Janesick, 1998; Raffan \& Barrett, 1989).

While journals have been used in a number of fields, they are also used for a variety of reasons as well. Journals may be used to stimulate thinking and assist students in developing writing skills (Kerka, 1996). As journal writing often reflects natural speech patterns, writing can be unencumbered and free-flowing. As Hammond (2002) stated, "Journal keeping can improve students' writing, enhance visual literacy, and provide them with an open opportunity to think and express themselves graphically, poetically, metaphorically, and informally” (p. 34). Depending on the type of course in which a student is enrolled, other reasons why journals have been used include: improved listening behaviour (Johnson \& Barker, 1995); sharing experiences (Hettich, 1990); helping women develop as "knowers" (Walden, 1995); and, encouraging reflection (Cantrell, 1997; Hughes \& Kooy, 1997). As diverse as the types of academic fields, so too are the intended reasons why instructors use journals.

Although journal writing has a long tradition, the research that has been conducted presents an unclear picture of how faculty perceive student journal writing. Many of the studies have only examined journal content, student experiences with journaling, or are based on anecdotal evidence. As Cole (1994) stated, "Unfortunately, much of the limited research on the use of journals has failed to establish meaningful goals, to provide challenging tasks, or to control for individual differences” (p. 138-139).

Journal writing has been found to be of positive value for students (Cole, 1994; Hettich, 1990). These benefits include: responsibility for learning belongs to the student, students are actively engaged in the reflective process, journal writing is a student-centered approach, journal writing may take on characteristics of natural speech, and students may shape knowledge as they see fit (see Hughes \& Kooy, 1997; Kerka, 1996). However, several problems with journal writing have also been noted, including overuse of journal writing in academic programs, use of the journal as a means of attacking others, "writing for the teacher," general dislike of journal writing, challenges related to evaluating journals, and lack of clear structure and purpose (Anderson, 1992; Chandler, 1997; Cole, 1994).

Studies examining student perceptions of journaling have been conducted mainly in the areas of literature and writing. Cole (1994) reported that students indicated journal writing stimulated thinking, required them to be focused while reading (instead of just "skimming" or for pleasure), and taught them to focus thoughts. Hettich (1990) found students preferred writing in a journal instead of a term paper as it allowed them to address a wider range of topics, was more personal in nature, and was a continuous process.

An article by Anderson (1992) begins to address faculty experiences with the journal writing process, but is based solely on the author's classroom experience and on informal conversations with other faculty at professional conferences. Little additional writing has described the faculty experience of using journals as a pedagogical tool. One intent of this article is to begin to fill the void of research in this area.

\section{Research Participants}

\section{Methods}

Using a purposeful sampling approach, we invited eight post-secondary faculty (five faculty, three instructors) to participate in this study that was conducted in November, 2003. Participants were selected based on the following criteria: 1) they were involved in teaching at least one course in outdoor recreation, experiential education, or outdoor education that had an 
outdoor field component (ranging from 3 hours to 12 days); 2) they required students to keep journals as part of their curriculum; and, 3) they assigned grades to student journals.

Descriptive statistics for demographic variables appear in Table 1 . There were three men and five women who participated in this study. In terms of percentage of courses in which these faculty asked students to write journals, responses ranged from 13 to 100 percent. In those courses that included a field component, faculty asked students to write journals from 50 to 100 percent of the time.

\section{INSERT TABLE 1 ABOUT HERE}

\section{Questionnaire}

The participants completed a 32-item questionnaire designed to evaluate their use and perceptions of journaling in post-secondary courses with a field component (See Appendix A). Twenty-seven of the items questioned faculty experiences with their own and student journal writing. The remaining five items elicited demographic information. This survey was modified from the one developed for earlier Phases of our research, and was intended to explore the themes that had emerged from the previous phases of this project. Generally, alphas were acceptable (.70 to .89). One variable was not included as its alpha value was unacceptable (.42).

\section{Focus Group Discussion}

To expand upon our findings from the questionnaires, we also conducted a focus group discussion. The interview questionnaires were designed to allow us to gain more insight, from a faculty perspective, into the themes emerging from earlier phases of the study, our review of the literature, as well as our analysis of the questionnaires.

Powell and Single (1996) defined a focus group as "a group of individuals selected and assembled by researchers to discuss and comment on, from personal experience, the topic that is the subject of the research" (p. 499). The recommended number of people in a focus group is usually six to ten. This small size is a crucial feature of focus groups in that participants are able to interact, by asking each other questions and by expanding on each other's ideas. A focus group was selected for this phase of the research in order to draw on the faculty's attitudes, feelings, beliefs, experiences, and reactions towards journaling in a way which would not be possible using solely other research methods, such as questionnaires or one-to-one interviewing (Kreuger, 1988; Morgan, 1997).

We facilitated a two-hour focus group with a goal of exploring main themes that had emerged from the literature as well as earlier phases of our research. A list of 13 questions (with many sub-questions) was used to guide the discussion (see Appendix B). Our role within the focus group was to facilitate the discussion, by encouraging the involvement of all participants and by limiting the domination of discussion by a few participants. We provided prompting questions to elicit expansion of interesting subtopics and challenged participants to share a diversity of perspectives on the topics under discussion. As facilitators, we were aware of the drawbacks of focus group research, such as the difficulty of separating individual viewpoints from the collective view point, and made every effort to fully explore the diversity of opinions within the group as well as the degree of consensus on given topics (Kreuger, 1988; Morgan, 1997).

A note taker was present during the focus group session. The session was also recorded on audiotapes and later transcribed. We listened to the tapes and read the transcriptions on multiple occasions with a view of performing a content analysis on the data. The material collected was then reduced by selecting, focusing, simplifying, abstracting and transforming the raw data (Miles \& Huberman, 1994). This is an on-going process throughout the duration of the research project. As Miles and Huberman note, 
As we see it, data reduction occurs throughout the life of any qualitatively oriented project. Even before the data are actually collected, anticipatory data reduction is occurring as the researcher decides (often without full awareness) which conceptual framework, which cases, which research questions, and which data collection approaches to choose. As data collection proceeds, further episodes of data reduction occur (writing summaries, coding, teasing out themes, making clusters, making partitions, writing memos). The data reduction/transforming process continues after fieldwork, until a final report is completed. (p. 10)

Strauss (1987) refers to this method of organization as the "conceptualization of data." The names of all participants in this study have been changed to protect their anonymity.

\section{Findings and Discussion}

\section{Current Practice of Journal Writing}

Although the perceptions of journal writing of faculty who participated in this study are influenced by the fact that their courses included a field component (i.e., time in the outdoors), many of their thoughts reflect those found in the existing literature and may be directly related to any faculty using journal writing as a pedagogical tool.

\section{Types of journals}

Study participants reported four main types of journals were being used in their courses. First, the faculty expected that journals be used to objectively record information for future use. Both Harris and Paul required objective "trip logs" that could be used to decrease legal liability. Paul provided his students with a template in which they could frame their experience in an objective way. This type of journal entry serves as documentation that the student actually participated in an activity, work experience, or event. Relatively little learning might occur from this type of journal entry. Although this is an easy way of recording this type of information, this may lead to "journaling burnout" as suggested by Anderson (1992).

Second, the faculty used journals as a method of encouraging students to respond to readings. As Keith indicated, "It gives them practice writing” and "practice in observation" related to what they have read. Study participants reported periodically collecting these journals at unannounced times during the semester in hopes that their students would stay current with class readings. Although this type of journal closely resembles those reported by Anderson (1992) and Hettich (1990), the intent of the journal is both for learning and perhaps primarily as a means of prompting students to read. The latter fact was not considered by the aforementioned authors.

Third, study participants encouraged students to use journals to make observations about nature. For example, Sarah wanted her students to slow down and "really notice things" like "where did you see that animal track?" Tina used journal writing as a means of assisting students in developing a connection to the land and a sense of place. This type of journal records observations about environment, context, or setting in which the student experience takes place, and is perhaps the type of journal most examined by other authors (Cole, 1994; Driver, 1997; Kerka, 1996; Raffan \& Barrett, 1989).

Finally, the faculty reported asking students to write journals as a subjective way of linking practical experience to course material. Journals were seen as a means of encouraging students to reflect on their field experiences and make connections with and extensions to what they had read and heard in class. When responding to a survey question asking, "I think that writing in journals is a helpful way to encourage reflection on field courses," faculty overwhelming indicated they agreed with this notion $(M=6.5, S D=.71)$. Additionally, the faculty indicated that they expected student self-assessment and self-reflection in journals. Harris noted he expected students "to be able to evaluate their own leadership." 
It appears that the types of journals faculty ask their students to keep span many of the levels of knowledge suggested by Bloom (1956), Cantrell (1997), and Young and Wilson (2000). This feature of journal writing may be an important aspect of the learning experience, especially for faculty who wish their students to go beyond memorizing facts and processes, and begin to make critical judgements about and extensions of the subject under study. Although these types of journals identified by the faculty in this study may not include all varieties used in academia, it is important to note the range of learning that may occur through each type indicated by the participants.

\section{Types of entries}

Within each type of journal mentioned above, the faculty reported that their students were including a number of different types of entries, many related to the overall purpose of the journal, and many as additional entries by the students for personal reasons, as a means of "spicing- up" their journal, or as supplementing faculty requirements of the assignment. Faculty indicated their students were: recording day-to-day events and happenings; making entries about personal growth and development; noting key developments in group dynamics; writing about sense of place and the environment; drawing pictures; and writing poetry. They reported students were not: making connections between class material and their experiences in the field; drawing maps of where they were; asking others to do "guest entries" in their journals; and synthesizing, evaluating, or making connections between/among theories and concepts. Results are shown in Table 2.

\section{INSERT TABLE 2 ABOUT HERE}

Based on findings from previous phases of our research, there is a clear discrepancy between what faculty expect students to write in journals and what students are actually writing. Congruent with our expectation, Wallace and Oliver (2003) hypothesized that preservice teachers would include more entries about their interactions with students as the semester progressed, and that students would reflect on a "deeper" level over the course of the semester. Wallace and Oliver found that only half of the students included passages about their relationships with students. However, they did find that by the end of the semester, most students had moved away from the superficial level of writing to the deeper levels of analysis, synthesis, and evaluation. Similarly, faculty participating in this study overwhelmingly assigned journal writing as a means of encouraging students to confront issues in a critical, evaluative, connective manner (i.e., at the "higher" levels of Bloom's Taxonomy (Bloom, 1956), or the "extensions" level of Young and Wilson's (2000) ICE Approach), but reported that students were not progressing to the "deeper" levels of reflection.

All the faculty in this study indicated they provided detail on what they expected from students in their course syllabi. August (2000) and Wallace and Oliver (2003) reported using their course syllabi as a means of providing information about journal writing. Wallace and Oliver included detailed rubrics that may have allowed their students to more fully understand what was expected from them. August used a short questionnaire to get feedback about the journal writing assignment. However, many faculty in our study indicated they only received feedback from students in an informal manner, and hoped that the students would appreciate journal writing assignments for reasons outlined in the syllabi. Other researchers have indicated this incongruence between faculty expectations and student performance as well as the lack of feedback mechanisms as two of the downfalls of journal writing (Anderson, 1992; Dyment \& O'Connell, 2003a; O'Connell \& Dyment, in press). 


\section{Process of journal writing}

An additional three items on the questionnaire asked the participants to report on the process they provided to their students or that they perceived their students adopted while writing journals. Participants reported being "Neutral" $(M=4.40, S D=2.07)$ in regards to providing structured time during field courses for journal writing and "Somewhat Agreed" in providing instruction in creative journal writing techniques $(M=4.7, S D=2.06)$. Participants "Agreed" that their students "wrote the majority of their entries at the end of the course shortly before they had to submit their journal for review" $(M=5.00, S D=1.41)$. These findings reflect results from earlier phases of our research (Dyment \& O’Connell, 2003; Dyment \& O’Connell, in press), and serve as confirmation of the recommendations of others that faculty must: provide adequate training, must clearly outline the process of journal writing, provide sufficient and timely feedback, and should model appropriate journaling behaviour and style (Bennion \& Olsen, 2002; Cole, 1994; Hettich, 1990).

\section{Perceptions of the Journal Writing Process}

\section{Why use journals?}

We were interested in knowing why faculty use journals instead of other, more conventional pedagogical tools (e.g., essays, exams, presentations). The faculty reported a wide range of reasons for using journals, suggesting that journal writing provides opportunities for students to: 1 ) have more freedom in expressing themselves and their learning; 2 ) reflect upon their own personal growth and development; 3) connect their field experiences to their in-class experiences; 4) develop their natural observation skills (e.g., weather, animal behaviour, plant identification); 5) draw on a wide range of types of intelligences (see H. Gardner, 1993); 6) develop their writing skills; 7) disrupt the focus on humans in the education system; and, 8) develop and intimate and embodied connection with the more than human realm.

\section{Quality}

We were also interested in knowing how faculty in the focus group perceived the quality of student journals. The faculty reported a range in the quality of journal entries. All faculty indicated that a modest percentage of journals were of poor quality, meaning that they were "mechanical," "totally descriptive," "the bare minimum," and even "insulting to mark." Harris explains, "In poor quality writing, I see just objective writing with no depth or richness. The student will write that the sun came up, it went down, we paddled and had lunch at two o'clock." The faculty also reported that the majority of journals met their expectations and a small percentage even exceeded their expectations. When we asked for an estimate of the percentage of journals that met their expectations, faculty reported that between 40 and $60 \%$ of the journals met their expectations. This is in contrast to the findings of August, (2000), Leighow Meo (2000), and Wallace and Oliver (2003), who reported that most of their students were generally meeting their expectations.

We were particularly interested in gaining an understanding of faculty perceptions of the quality of student journals given the conflicting findings that had emerged in earlier phases of the research. In Phase 3 of the research, we performed a focus group discussion with nine students studying outdoor recreation (Dyment \& O'Connell, 2003b). These students were in the same program as the faculty are who participated in this phase of the study. Students in the focus group reported that they were advanced journal writers and that journals were a venue for critically evaluating their learning, experiences, instructors, and themselves. Yet in Phase 4 of this study, when we performed a content analysis on 880 journal entries of the students in this same program, we found that the majority of entries were fairly descriptive and that critical reflection, by and large, was absent. As previously noted, faculty in this study overwhelmingly thought journals were a helpful way to encourage reflection. However, counter to this belief, they 
recognized that students were not making connections between what they had learned in class and what they experienced in the field. Other researchers, such as Anderson (1992), have also raised concerns about the quality of student journals. In reflecting upon the journal entries he read, Anderson notes that most entries have "no evidence of analysis, synthesis, deliberation, or reflection" (p. 307). Contrary to these findings, Wallace and Oliver (2003) found that their students were generally writing at "deeper" levels near the end of the semester.

When we explained these conflicting findings between Phase 3 and Phase 4, the faculty had many explanations as to why the students might have inadequate and elevated perceptions of their journal writing abilities. Anna suggested that lack of preparation might explain why some of the journals are of poor quality. She explains "I think there is a real lack of adequate preparation for how to write journals...the students are so used to writing for us in an academic context that they can't figure out how to write without instruction." She continues, "The students have been asked to copy, summarize, and regurgitate for 14 years... and then we want them to critically reflect, think, and write in their journals...no wonder they look a little transfixed when I give them a journal assignment...like 'what's this?'” Keith wondered if they weren't getting enough good feedback, suggesting that "They [the students] are either fooling you, fooling themselves, or perhaps, more likely, we haven't done a good enough job of showing them or giving them feedback on what good quality means." With these limitations in mind, we now turn the question of evaluating and assigning marks to student journals.

\section{Evaluation}

As many researchers have noted, evaluating journals can be a complicated, repetitive, daunting, time consuming, and ethically challenging task (Chandler, 1997; Ediger, 2001; Hettich, 1990). Anderson (1993) provides an excellent overview of problems with grading journals. He questions whether journals should be marked at all. Depending on the grading scheme, it might not "reward" student appropriately (e.g., consistently high quality journals get the same mark as low quality journals based on number of entries). In the reverse instance, many students may write many entries, but only summarize readings or experiences. These students feel "cheated" when receiving lower grades than their more reflective counterparts. In agreement with Anderson, Kerka (1996) recognizes the problem of marking something that may be expressly written for what the teacher wants to see. Kerka also raises issues of privacy and the teacher-learner relationship, and how perceptions of traditional power imbalances may potentially affect marking.

With a view of understanding faculty perceptions of evaluating journals, we asked the faculty a variety of questions about grading journals, both in the focus group and in the questionnaire. Faculty "Agreed" with the question, "I think journals are a useful evaluation tool for assessing learning in university courses," $(M=5.7, S D=1.42)$. Faculty in the focus group reported that journals were worth between 10 and $25 \%$ of the final course grade. A number of evaluative systems were used, including rubrics, templates, pass/fail, and "subjective feelings." Some faculty provided mid-term evaluations of journals. However, responses to the questionnaire item, "I provide a mid-course check in with my students to ensure that they are on the right track with their journals" elicited a "Somewhat Disagree" to "Neutral” reply $(M=3.60, S D=2.22)$. Some faculty provided the grading criteria in the course outline, while others were "intentionally vague.” The percentage of the final mark that these faculty assigned to student journals ranged from 10 to 30 percent. This is consistent with the findings of previous studies (Hettich, 1990).

The faculty in the focus group noted the challenges of evaluating journals in a fair and consistent manner. While objective entries (e.g., weather, sightings, dates, route) are fairly easy to grade via a list of predetermined criteria, the faculty reported that it becomes more difficult to evaluate the subjective (e.g., reflections) journals. Paul described (in a rather embarrassed manner) how he evaluated subjective journals: 
Is there something written? Yes? They're getting at least 6/10. Is there some connection to what is going on in the field or class? Yes? It would go up by almost a point. Is there some theme they've developed? Yes? Throw on another point.

Many of the faculty agreed their approach was not too different from Paul's: indeed it appears to be very difficult to evaluate, in an objective manner, a subjective journal entry. August (2000) agreed with the difficulties in grading journal entries, but noted "To be taken seriously, the journal entries must affect grades...” (p. 345).

Study participants all agreed that providing written comments on journals is critical. Harris asserted that "the qualitative comments are the most powerful things students will take away from their evaluation...it is what they will remember and learn the most from.” Yet providing thorough and thoughtful evaluations with feedback can be difficult when you have got a large class size, and require students to hand in journals several times during a semester (August, 2000). Cecilia wondered about her ability to give feedback "when I have 60 journals sitting on my desk...II wonder if I'll be honest enough, critical enough, write enough comments, give enough time...it can just feel so overwhelming."

We asked the faculty if they thought the students were "writing for the teacher," a phenomenon observed by Anderson (1992, p. 307) and reported by the students in our previous focus group (Phase 3) (Dyment \& O'Connell, 2003b). Some faculty agreed, reporting that when journals were evaluated, students were less focussed on being creative, critical, and reflexive, instead directing their energies towards trying to meet the evaluative criteria. "Grading journals," Tina noted, "seems to get in the way of good pedagogy." To that end, some faculty were in support of a pass/fail system for journals. Tina described her positive experience with a pass/fail system as a student in her graduate work, "it was incredibly freeing and I wrote much more creatively, much more critically, I was much more willing to take chances, to be contrary to the professor, go out on a limb...because I knew I was going to pass...”

Overall, it appears this group of faculty believe in the potential of journals as a positive tool to encourage reflection and learning. However, it appears as though these faculty struggle with many of the same issues recognized in the existing literature on journaling (i.e., writing for the teacher, issues/concerns in marking, etc.). We asked these faculty for recommendations on how to overcome some of these hurdles to using journals effectively in a university setting.

\section{$\underline{\text { Reflections and Suggestions for Improvement }}$}

By and large, the faculty who participated in this study appreciated the pedagogical potential of journal writing within the formal university system. When asked what faculty could do to facilitate more successful journal writing, they provided several suggestions, many of which they currently practiced.

Many study participants suggested alternative marking schemes that could be used for journal assignments, a suggestion that has been offered by others (e.g., Anderson, 1992; Chandler, 1997; Hammond, 2002). Cecelia wondered if pass/fail marking would be adequate. Tina, when commenting on using this approach in the past, supported this scheme in a pedagogical and practical manner, "Pass/fail was incredibly freeing. I took chances to go out on a limb." She also remarked, "It was wonderful for me as a teacher because I gave all sorts of qualitative feedback and helped them improve... - I hate grading!” Anna concurred, "It's amazing!” Tina also suggested using a rubric, as suggested by other researchers (Hammond, 2002; Moutoux, 2002; Wallace \& Oliver, 2003). She noted that using rubrics are generally easy. Rubrics also provide a framework in which students may write. Other faculty suggested that the journals not be included in the marking scheme. Paul commented that he had once only considered journals as part of an overall participation mark, and that "Over that year, there was a definite improvement [in the quality of journals].” 
Study participants also encouraged alternative forms of journaling. Claire suggested that traditional, written journals may not serve the needs of all students. She proposed that students could keep a video journal of their experiences, and share that with the instructor and the rest of the class. Sarah encouraged her students to draw and include samples of natural objects in their journals. She arranged for a local artist to come to her class and provide elementary instruction for her students. Audio taped journals, art work, and other creative types of journals were also suggested.

Study participants unanimously supported the need to provide ongoing training and support in journal writing technique. Consistent with our prior research (O'Connell \& Dyment, 2003), and recommendations of others (Anderson, 1992), participants in the focus group suggested a wide variety of ways to ensure students understood the journal writing process. Claire recommended that exemplars of journals be placed on library reserve or supplied to students in some other manner. Sarah agreed, indicating that she puts the book, Nature Journaling: Learning to Observe and Connect with the World Around You (Leslie \& Roth, 1998) on reserve in the library. Tina started including examples in her reading package for courses so students would have good indicators of what journal entries may look like. Training can also come through the form of regular feedback to students. Both written and verbal feedback from instructor, teaching assistants, or peers can help students improve their writing.

Finally, faculty in the focus group agreed with Claire's statement that, "Enthusiasm is contagious!" Study participants strongly agreed that instructors who wish to utilize journal writing in their courses must approach the process with a positive perspective. They must be prepared to counter the feeling that students have been "journaled to death" (Anderson, 1992). To maintain positive energy for journaling, faculty within the same department must collaborate to avoid the overuse of journals leading to "burnout." Building on that concept, Sarah suggested that if journals were used throughout a program, a "journaling across the curriculum" approach could be taken. Burnout can also stem from the students' prior negative experience with journals in which they have not been allowed to creatively or meaningfully reflect on matters they find relevant. As Tina said, “For some students, they don't want to do it [journaling]. So they do the bare minimum, they look at my little rubric of what I'm expecting; they do the bare stuff because they don't find any value in it."

As some study participants suggested, however, the challenges to journaling in higher education lie much deeper. Faculty and education systems are often limited by conventional assumptions about education: about the need for teachers to be "experts" in a subject area, about the under-reliance on student experiences, about the need to quantitatively evaluate all aspects of student learning. Such assumptions lie uneasily with the realities of journal writing, where the students are drivers of their own learning, where outcomes are less easy to control and more difficult to measure, and where learning experiences are more fully embodied.

The recommendations of these faculty are influenced by the context of how they use journals (i.e., through courses including an outdoor field component). However, these recommendations, based on both a qualitative and quantitative systematic examination of how faculty employ journal writing, have confirmed the anecdotal and research-based evidence supplied by others (Anderson, 1992; Arredondo \& Rucinski, 1994; Bennion \& Olsen, 2002; Bocarro, 2003; Burt, 1994; Cantrell, 1997; Chandler, 1997; Cole, 1994; Dyment \& O'Connell, 2003a; Ediger, 2001; Hammond, 2002; Hettich, 1990; Kerka, 1996; Murray, 1997; O'Connell \& Dyment, in press; Raffan \& Barrett, 1989; Walden, 1995; Wallace \& Oliver, 2003). These findings may be easily adapted to most academic disciplines, and many styles of journal writing. Additionally, there is sufficient evidence to warrant a carefully planned and structured approach to journal writing. We implore faculty who wish to start using journal writing with students, as well as those experienced with this practice, to consider the intended outcomes, personal commitment, available resources, as well as the benefits and downfalls of journaling before, during and after assigning journal writing as part of coursework. 


\section{Conclusion}

In this study, we explored faculty perceptions of journaling with eight post-secondary recreation faculty members and instructors. While enthusiastic of the benefits, they also commented on the untapped potential of journals. They were cautious about some aspects of the journaling process and described numerous constraints embedded within the dominant culture of the educational system that limit the full potential of journal writing to be realized. Journal writing seems to be counter to many of the hegemonic foundations within a typical university. We have summarized many of their suggestions and encourage faculty to consider their recommendations.

Given the small sample used in this study, we recognize the limits of generalizing the findings to larger populations, such as university classes using journals as a method of teaching and/or evaluation. The findings of this study do, however, provide a greater understanding of the issues that emerged in earlier Phases of our research. The findings also set the stage for more ambitious explorations of the role of journaling in higher education.

We conclude by noting that study participants unanimously indicated that they learned a great deal about journaling through their participation in this research. By completing the questionnaire and participating in the focus group, the faculty were given a rare opportunity to reflect upon their own experiences with journal writing; they were able to share their journal ideas regarding what has and has not worked; and, they were able to learn innovative ideas for using journals in their own teaching. Too often, we suspect, as Anna did, that university professors are left to "know it all... and most of us haven't been trained in teaching.” Anna admits that she started using journals "because everyone else was doing it here." Perhaps this research also points to the need for faculty in higher education institutions to develop a culture of collaboration and sharing so that effective teaching ideas can be exchanged among faculty. 
Table 1

Means and Standard Deviations for Demographic Variables

\begin{tabular}{|c|c|c|c|c|}
\hline Source & Minimum & Maximum & $M$ & $S D$ \\
\hline Years as a university professor & 1 & 20 & 6.40 & 5.21 \\
\hline Age & 28 & 44 & 36.00 & 5.25 \\
\hline $\begin{array}{l}\text { Number of courses taught per } \\
\text { year }\end{array}$ & 3 & 8 & 5.00 & 1.33 \\
\hline $\begin{array}{l}\text { Number of courses taught per } \\
\text { year which include a field } \\
\text { component }\end{array}$ & 1 & 4 & 2.30 & 1.42 \\
\hline
\end{tabular}


Table 2

Types of Entries Reported in Student Journals By Faculty

\begin{tabular}{|c|c|c|}
\hline Question & $M$ & $S D$ \\
\hline $\begin{array}{l}\text { My students make entries about the day-to-day events and } \\
\text { happenings (where they were, what they did, weather, etc.). }\end{array}$ & 6.20 & 1.03 \\
\hline My students make drawings in their journals. & 5.90 & .88 \\
\hline $\begin{array}{l}\text { My students make entries about the environment and about sense } \\
\text { of place. }\end{array}$ & 5.80 & .92 \\
\hline My students write poetry in their journals. & 4.90 & 1.66 \\
\hline My students make entries about personal growth and development. & 4.70 & 1.57 \\
\hline $\begin{array}{l}\text { In my students' journals, they try to make connections between } \\
\text { their experiences on the course and their 'every-day life.' }\end{array}$ & 4.40 & .97 \\
\hline $\begin{array}{l}\text { My students make entries about the group dynamics that were } \\
\text { happening. }\end{array}$ & 4.00 & 2.54 \\
\hline My students draw maps of where they were. & 3.90 & 1.29 \\
\hline My students only report factual information in their journal entries. & 3.70 & 1.70 \\
\hline $\begin{array}{l}\text { My students' journal entries synthesize, evaluate, or make } \\
\text { connections between/among theories and concepts. }\end{array}$ & 3.50 & 1.96 \\
\hline $\begin{array}{l}\text { In my students' journals, they are able to make connections } \\
\text { between material they have learned in other university classes and } \\
\text { their experience in field courses. }\end{array}$ & 3.40 & 1.84 \\
\hline $\begin{array}{l}\text { My students have other students and instructors do "guest entries" } \\
\text { in their journals. }\end{array}$ & 1.70 & 1.34 \\
\hline
\end{tabular}

Note. Based on a series of 7-point Likert scales, where 1 represents "strongly disagree", 4 represents "neutral," and 7 represents "strongly agree." 


\section{References}

Anderson, J. (1992). Journal writing: The promise and the reality. Journal of Reading, 36(4), 304-309.

Arredondo, D. E., \& Rucinski, T. T. (1994). Using reflective journals and the workshop approach in university classes to develop students' self-regulated learning. (ERIC Document Reproduction Service No. ED 404 892).

August, A. (2000). The reader's journal in lower-division history courses: A strategy to improve reading, writing and discussion. The History Teacher, 33(3), 343-348.

Bennion, J., \& Olssen, B. (2002). Wilderness writing: Using personal narrative to enhance outdoor experience. Journal of Experiential Education, 25(1), 239-246.

Bloom, B. S. (Ed.). (1956). Taxonomy of educational objectives. New York: Longmans-Green.

Bocarro, J. (2003). Maintaining the balance between service and learning: The use of journals in promoting critical thinking. Schole: A Journal of Leisure Studies and Recreation Education, 18, 7-22.

Burt, C. (1994). An analysis of self-initiated coping behaviour: Diary-keeping. Child Study Journal, 24(3), 171-190.

Cantrell, J. (1997). K-W-L learning journals: A way to encourage reflection. Journal of Adolescent and Adult Literacy, 40(5), 392-394.

Chandler, A. (1997). Is this for a grade? A personal look at journals. English Journal, 86(1), 4549.

Cole, P. (1994). A cognitive model of journal writing. Proceedings of Selected Research Presentations at the 1994 National Convention of the Association for Educational Communications and Technology, Nashville, TN.

Driver, J. (1997). The place of journal writing on an outdoor experience. Journeys, 2(4), 24.

Dyment, J. E., \& O'Connell, T. S. (2003a). Journal writing in experiential education: Possibilities, problems and recommendations. Eric Digest. Charleston, WV: ERIC Clearinghouse on Rural Education and Small Schools. (ERIC Document Reproduction Service No. EDO-RC-03-05).

Dyment, J. E., \& O'Connell, T. S. (2003b). "Journal writing is something we have to learn on our own" - The results of a focus group discussion with recreation students. Schole: A Journal of Leisure Studies and Recreation Education, 18, 23-38.

Dyment, J. E., \& O'Connell, T. S. (in press). Student perceptions of journaling as a reflective tool in experience-based learning. The Journal for the Art of Teaching.

Ediger, M. (2001). The student, journal writing, and assessment. (ERIC Document Reproduction Service No. ED 499 195).

Gardner, H. (1993). Multiple intelligences: The theory in practice. New York, NY: Basic Books.

Gardner, S., \& Fulwiler, T. (Eds.). (1999). The journal book: For teachers in technical and professional programs. Portsmouth, NH: Boynton/Cook Publishers.

Grumet, M. R. (1990). Retrospectives: Autobiography and analysis of educational experience. Cambridge Journal of Education, 20(3), 32-37.

Hammond, W. (2002). The creative journal: A power tool for learning. Green Teacher, 69, 34-38.

Hettich, P. (1990). Journal writing: Old fare or nouvelle cuisine. Teaching of Psychology, 17(1), 36-39.

Hughes, H. W., \& Kooy, M. (1997). Dialogic reflection and journaling. Clearing House, 70(4), 187-191.

Janesick, V. J. (1998). Journal writing as a qualitative research technique: History, research, and reflections. (ERIC Document Reproduction Service No. ED 420 702).

Johnson, I. W., \& Barker, R. T. (1995). Using journals to improve listening behaviour. Journal of Business and Technical Communication, 9(4), 473-484.

Kerka, S. (1996). Journal writing and adult learning. ERIC Document ED 339413. 
King Jr., W. C. (1998). A semester-long experiential exercise to develop workplace understanding: The role assignment exercise. Journal of Management Education, 22(6), 720-736.

Kreuger, R. A. (1988). Focus groups: A practical guide for applied research. London: Sage.

Leighow Meo, S. (2000). "In their own eyes:" Using journals with primary sources with college students. The History Teacher, 33(3), 335-341.

Leslie, C., \& Roth, C. (1998). Nature journaling: Learning to observe and connect with the world around you. Pownal, VT: Storey Books.

Miles, M. B., \& Huberman, A. M. (1994). Qualitative data analysis ( $2^{\text {nd }}$ ed.). Beverly Hills, CA: Sage Publications.

Morgan, D. L. (1997). Focus groups as qualitative research (2nd ed.). London: Sage.

Moutoux, M. (2002). Evaluating nature journals. Green Teacher, 69, 39-40.

Murray, S. (1997). The benefits of journaling. Parks and Recreation, 32(5), 68-74.

O'Connell, T. S., \& Dyment, J. E. (2003). Effects of a journaling workshop on participants in university outdoor education field courses: An exploratory study. Journal of Experiential Education, 26(2), 75-87.

O'Connell, T. S., \& Dyment, J. E. (2004). Journals of post secondary outdoor recreation students: The results of a content analysis. Journal of Adventure Education and Outdoor Learning, 4(2), 159-172.

Powell, R. A., \& Single, H. M. (1996). Focus groups. International Journal of Quality in Health Care, 8(5), 499-504.

Raffan, J., \& Barrett, M. J. (1989). Sharing the path: Reflections on journals from an expedition. Journal of Experiential Education, 12(2), 29-36.

Steiner, B., \& Phillips, K. (1991). Journal keeping with young people. Englewood, CO: Libraries Unlimited.

Strauss, A. (1987). Qualitative analysis. New York: Cambridge University Press.

Walden, P. (1995). Journal writing: A tool for women developing as knowers. New Directions for Adult and Continuing Education, 65, 13-20.

Wallace, C. S., \& Oliver, J. S. (2003). Journaling during a school-based secondary methods course: Exploring a route to teacher reflection. Journal of Science Teacher Education, 14(3), 161-176.

Young, S.F., \& Wilson, R.J. (2000). Assessment and learning: The ICE approach. Winnipeg, Manitoba: Peguis. 
Appendix A

Faculty Journaling Questionnaire

Please respond to the following questions using this scale:

\begin{tabular}{|cccccccc|}
\hline $\mathbf{0}$ & $\mathbf{1}$ & $\mathbf{2}$ & $\mathbf{3}$ & $\mathbf{4}$ & $\mathbf{5}$ & $\mathbf{6}$ & $\mathbf{7}$ \\
Irrelevant & $\begin{array}{c}\text { Strongly } \\
\text { disagree }\end{array}$ & Disagree & $\begin{array}{c}\text { Somewhat } \\
\text { disagree }\end{array}$ & Neutral & $\begin{array}{c}\text { Somewhat } \\
\text { agree }\end{array}$ & $\begin{array}{c}\text { Agree } \\
\text { Atrongly } \\
\text { agree }\end{array}$ \\
\hline
\end{tabular}

1. At this moment, in my life outside of teaching, I keep a regular journal

$0 \begin{array}{lllllll}0 & 1 & 3 & 4 & 5 & 6 & 7\end{array}$ to record my daily thoughts and activities.

2. While on field courses, I keep a regular journal to record my daily thoughts and activities.

3. I plan on keeping a journal in the future.

$0 \begin{array}{lllllll}0 & 2 & 3 & 4 & 5 & 6\end{array}$

4. I provide structured time during field courses for journaling.

$\begin{array}{lllllllllll}0 & 1 & 2 & 3 & 4 & 5 & 6 & 7\end{array}$

5. I provide instruction in/examples of creative journal entries to my

$\begin{array}{lllllllll}0 & 1 & 2 & 3 & 4 & 5 & 6 & 7\end{array}$ students.

6. It seems like my students write the majority of their entries at the end of the course shortly before they had to submit the journal for review.

7. I think that writing in journals is a helpful way to encourage reflection on field courses.

8. It is difficult for me to find time to write in my own journal during field courses.

9. I do not make regular entries during field courses.

10. My students make entries about the day-to-day events and happenings (where they were, what they did, weather, etc.).

11. In my students' journals, they try to make connections between their experiences on the course and their "every-day life."

12. My students make entries about personal growth and development.

13. My students do not make entries about the group dynamics that were happening.

14. My students make entries about the environment and about sense of place.

15. In my students' journals, they are unable to make connections between material they have learned in other university classes and their experience in this field course.

16. My students draw maps of where they were.

17. My students have other students and instructors do "guest entries" in

012334566

$0 \begin{array}{lllllll}0 & 1 & 3 & 4 & 5 & 6 & 7\end{array}$

01234567

$0 \begin{array}{lllllll}0 & 1 & 2 & 4 & 5 & 6 & 7\end{array}$

$\begin{array}{llllllllll}0 & 1 & 2 & 3 & 4 & 5 & 6 & 7\end{array}$

$\begin{array}{llllllll}0 & 1 & 2 & 3 & 4 & 5 & 6 & 7\end{array}$

$0 \begin{array}{lllllll}0 & 1 & 2 & 3 & 4 & 5 & 6\end{array}$

$\begin{array}{llllllllll}0 & 1 & 2 & 3 & 4 & 5 & 6 & 7\end{array}$

$\begin{array}{llllllll}0 & 1 & 2 & 3 & 4 & 5 & 6 & 7\end{array}$

$0 \begin{array}{lllllll}0 & 2 & 3 & 4 & 5 & 6 & 7\end{array}$

$0 \begin{array}{lllllll}0 & 1 & 2 & 3 & 4 & 5 & 6\end{array}$ their journals.

18. My students make drawings in their journals.

19. My students do not write poetry in their journals.

20. I give students supplies to use for journaling while on field courses (e.g., crayons, markers, tape, glue, etc.)

21. I think journals are a useful evaluative tool for assessing learning in university courses.

$\begin{array}{|cccccccc|}\mathbf{0} & \mathbf{1} & \mathbf{2} & \mathbf{3} & \mathbf{4} & \mathbf{5} & \mathbf{6} & \mathbf{7} \\ \text { Irrelevant } & \begin{array}{c}\text { Strongly } \\ \text { disagree }\end{array} & \text { Disagree } & \begin{array}{c}\text { Somewhat } \\ \text { disagree }\end{array} & \text { Neutral } & \begin{array}{c}\text { Somewhat } \\ \text { agree }\end{array} & \text { Agree } & \begin{array}{c}\text { Strongly } \\ \text { agree }\end{array}\end{array}$


22. My students only report factual information in their journal entries.

$\begin{array}{llllllllll}0 & 1 & 2 & 3 & 4 & 5 & 6 & 7\end{array}$

23. My students avoid writing about certain things because they know that the journal is going to be reviewed.

24. My students' journal entries synthesize, evaluate or make connections between/among theories and concepts.

25. I think that journals are too personal to be reviewed.

0122345667

$\begin{array}{llllllll}0 & 1 & 2 & 3 & 4 & 5 & 6 & 7\end{array}$

26. I provide a mid-course check-in with my students to ensure that they are on the right track with their journals.

27. It seems as though my students end up writing "what the instructor wanted.”

28. How many years have you been a university/college professor?

29. What is your gender? Male Female

30. What is your age?

31. How many courses of all types do you teach per year?

i. In what percentage of all your courses do you ask students to write journals? (e.g., 1 out of 5 courses $=20 \%$ )

32. How many courses do you teach per year that include a field component?

i. In what percentage of your courses that include a field component do you ask students to write journals? 
Appendix B

Questions for Focus Group with Faculty

1. Tell us about when you've asked students to journal in university courses.

a. What do you like about having students journal for university courses?

b. What do you dislike about having students journal for university courses?

2. What do your students write about when you ask them to journal for courses?

a. Do they make links between the course and their field experience?

b. Do they make links between their field experience and professional development?

c. Do they make links between their field experience and other courses?

d. Do they connect practical experience with theory/stuff they've learned in books/lecture?

e. Why or why not for each and explain.

3. How do you evaluate journals? Should they be evaluated at all? How much of your final mark is the journal worth?

4. What are the biggest barriers to journaling on field courses?

a. Probes about time:

i. Structured time in field?

ii. Enough time?

iii. When are students writing?

b. Activities and physical environment (i.e., dogsledding, winter, rain).

5. How creative are your students when they journal?

a. What factors inhibit their creativity? Why?

b. What factors increase their creativity? Why?

c. Do you feel students can be creative and still meet your requirements/expectations?

d. Do your students use special materials/supplies when they journal? (e.g., glue, tape, colored markers, pencils, and crayons).

i. Do your students add other items to their journals? (e.g., photos, stickers, cutouts, etc.).

ii. Do your students decorate the cover/outside of their journals?

6. Are your students proud of their journals when they are done writing it?

a. What about their journals makes them proud?

b. What about their journals are they not proud of?

c. Does your feedback affect how proud students are of their journals?

7. What types of feedback do you give as an evaluator?

a. Written comments?

b. Personal meeting time to go through it together?

8. Do you feel students write differently for different evaluators? Why? (Trust, previous experience with instructor, whether or not evaluator was in field with you).

9. What is your concept of "good journaling behavior?"

a. Do you or your field staff model this behavior?

b. Do other faculty members model this behavior?

c. What would make it easier to encourage students to have good journaling behavior?

10. Gender differences:

a. (How) do men and women differ in their perceptions and experience of journaling? Why?

b. Does it make a difference if the student is the opposite gender than you? 
11. What do you think students need to journal successfully?

12. Students have told use they'd like to learn more about journaling. What do you think are important things for students to learn about journaling for university courses? 